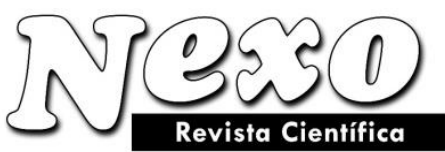

Vol. 34, No. 01, pp. 103-111/Marzo 2021

\title{
Ensuring the integrity of the road network as the key to solving the problems of highway capacity in cities
}

\section{Garantizando la integridad de la red vial como clave para resolver los problemas de capacidad de carreteras en las ciudades}

\author{
Arkady V. Zakharov*, Tatiana R. Zabalueva \\ Moscow State University of Civil Engineering, Moscow, Russia. \\ *zakharov.arkady@yandex.ru
}

(recibido/received: 03-January-2021; aceptado/accepted: 17-February-2021)

\begin{abstract}
Broadband highways are being built in major cities around the world to combat traffic congestion. At the same time, existing buildings are demolished or powerful overpasses are raised above them. However, it often turns out that newly created highways quickly exhaust their capacity, and traffic jams are formed on them again. This situation indicates that increasing the capacity of the highway does not solve the problem of traffic jams, but often aggravates it, since as a result of this increase, even more cars are drawn to the highway from adjacent territories, often exceeding their current capacity. At the same time, the streets in the surrounding areas are empty and their potential is not used to the full extent. This situation has arisen due to the disruption of the city road network by lengthy obstacles in the form of ravines, rivers, floodplains of small rivers, and railways. This situation can be corrected by "stitching" the streets over the gaps by building bridges and overpasses with a capacity corresponding to the capacity of the "stitched" streets. Most of the gaps fall on relatively small streets, which approach the banks of fairly wide floodplains of small rivers and streams, and this makes it advisable to build mainly small (with a span of 20-25 m) and relatively inexpensive bridges, with the number of spans sufficient to cover the floodplain and reach the levels of road surfaces of connected streets. There will be several hundred such bridges over the river barriers in a large city, for example, Moscow, and several hundred more, taking into account the required number of them over the railways, and in the end, about a thousand. It is proposed to erect bridge buildings instead of simple road bridges. Such structures combine two city functions; the first of them is transport, the second is public, residential, or economic, depending on the needs of the city and the environmental situation at the construction site. An important requirement for the second function is a quick return on the financial assets invested in the construction and income from the operation of the building acceptable to the investor. The bridge part of a bridge building should become the property of the city.
\end{abstract}

Keywords: traffic capacity of streets, lengthy obstacles, congestion, stitching of gaps in the road network, bridge buildings.

\section{RESUMEN}

Se están construyendo carreteras de banda ancha en las principales ciudades del mundo para combatir la congestión del tráfico. Al mismo tiempo, se derriban edificios existentes o se levantan poderosos pasos a 
desnivel sobre ellos. Sin embargo, a menudo resulta que las carreteras recién creadas agotan rápidamente su capacidad y se vuelven a formar atascos en ellas. Esta situación indica que aumentar la capacidad de la carretera no resuelve el problema de los atascos, pero muchas veces lo agrava, ya que como consecuencia de este aumento, se atraen aún más automóviles a la carretera desde territorios adyacentes, muchas veces superando su capacidad actual. Al mismo tiempo, las calles de los alrededores están vacías y su potencial no se aprovecha al máximo. Esta situación se ha producido debido a la interrupción de la red vial de la ciudad por largos obstáculos en forma de barrancos, ríos, llanuras aluviales de pequeños ríos y vías férreas. Esta situación puede corregirse "cosiendo" las calles sobre los huecos mediante la construcción de puentes y pasos superiores con una capacidad correspondiente a la capacidad de las calles "cosidas". La mayoría de los huecos caen en calles relativamente pequeñas, que se acercan a las riberas de llanuras aluviales bastante amplias de pequeños ríos y arroyos, por lo que es aconsejable construir puentes principalmente pequeños (con una luz de $20-25 \mathrm{~m}$ ) y relativamente económicos, con el número de vanos suficientes para cubrir la llanura aluvial y alcanzar los niveles de superficies de carreteras de calles conectadas. Habrá varios cientos de puentes de este tipo sobre las barreras fluviales en una gran ciudad, por ejemplo, Moscú, y varios cientos más, teniendo en cuenta el número requerido de ellos sobre los ferrocarriles, y al final, alrededor de mil. Se propone la construcción de puentes en lugar de simples puentes de carretera. Tales estructuras combinan dos funciones de la ciudad; el primero de ellos es el transporte, el segundo es público, residencial o económico, según las necesidades de la ciudad y la situación ambiental en la obra. Un requisito importante para la segunda función es un rápido retorno de los activos financieros invertidos en la construcción y los ingresos de la operación del edificio aceptables para el inversor. La parte del puente de un edificio puente debe convertirse en propiedad de la ciudad.

Palabras clave: capacidad de tránsito de calles, obstáculos largos, congestión, costura de huecos en la red vial, edificios de puentes.

\section{INTRODUCTION}

\section{The relevance of the study}

The road networks of most major cities are cut by numerous insurmountable obstacles for cars to pass through. The importance of the problem of "stitching" the road networks of cities, can be seen in the example of the city of Moscow, on the territory of which there are a large number of obstacles such as railways, ravines, small and large rivers, etc., tearing the road network. These issues are presented in detail in the works of T.R. Zabalueva and E.I. Kocheshkova (Zabalueva, Zakharov, Kocheshkova, 2013; Kocheshkova, 2013), which refer to scientific research that has been conducted for many years at the Department of Architecture of the Moscow State University of Civil Engineering (MSUCE). Bridges and overpasses are erected over the railways to solve the problems of the road network disruption. As the demand for free areas for construction and development of the road network grows, many streams and rivers are hidden in underground collectors, which makes it possible to organize passages in these places, that is, to "stitch" the road network. Larger rivers are equipped with transport and pedestrian embankments, coastal park areas, and rare automobile bridges. The total length of land plots along the rivers suitable for the necessary building is about $150 \mathrm{~km}$, but besides the congestion of the embankments with traffic flows, the problem is not solved, since all traffic flows tend to the main highways provided with bridges.

Consider the situation using the example of the small Yauza River, which has its origins in the Moscow national park Losiny Ostrov and flows initially to the northwest to Mytishchi, then returns from the north to Moscow and, having passed about $30 \mathrm{~km}$ along it, flows into the Moscow River in the center of the city. 


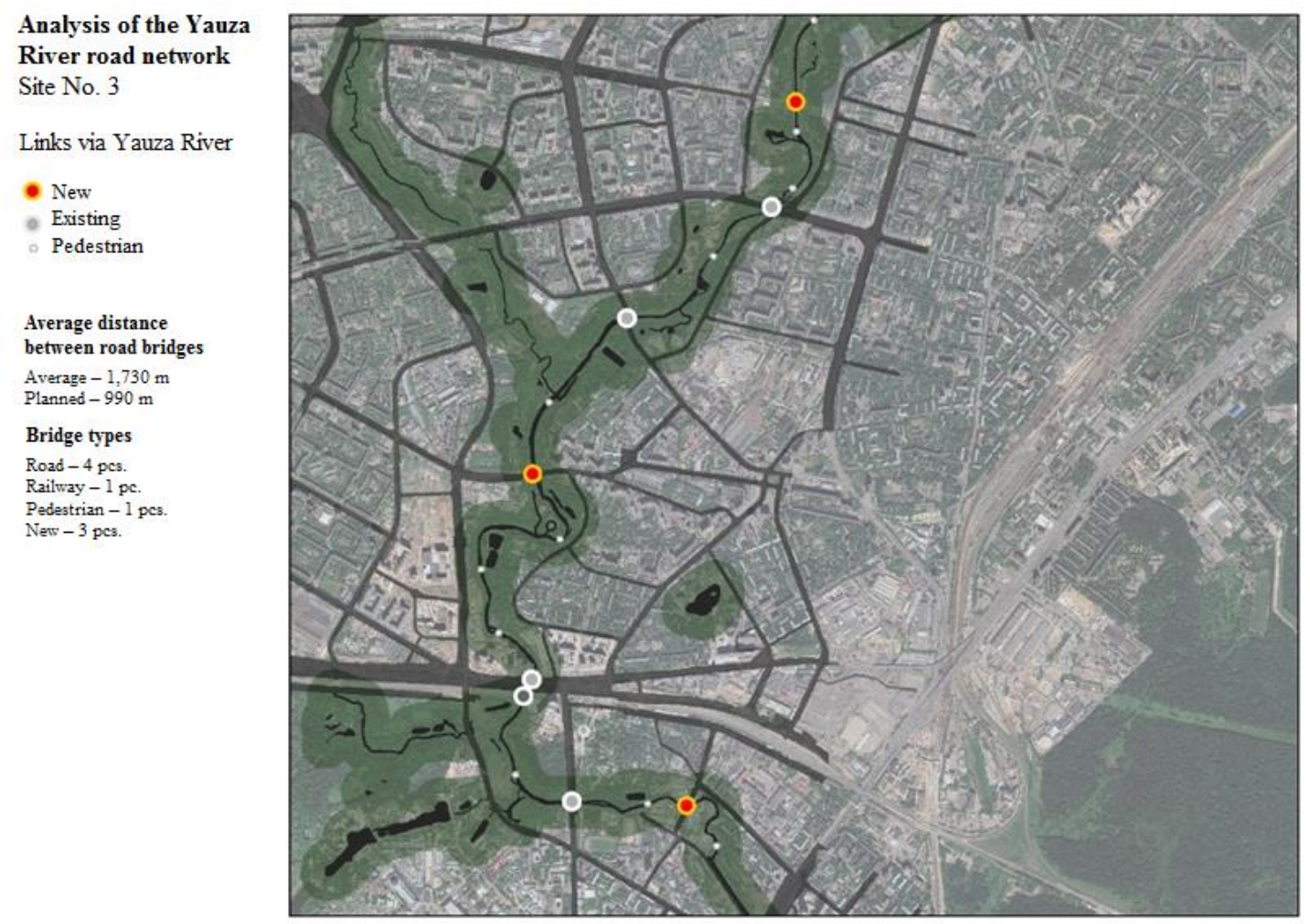

Figure 1. Analysis of the road network on a fragment of the Yauza River floodplain between the Medvedkovo and Sokolniki-Bogorodskoe districts

Figure 1 shows transport links across the Yauza, investigated by the architect A.M. Andrienko, on its typical $7.9 \mathrm{~km}$ long fragment, on which there are seven road bridges (of which three are new) and 11 pedestrian bridges (Andrienko, 2020). The distance between road bridges is from 820 to $1,730 \mathrm{~m}$. Pedestrian bridges are evenly spaced along the entire length of the fragment under consideration and, naturally, are located in those places where streets approach the river floodplain. The average distance between all bridges, considering that road bridges have sidewalks, is just over $400 \mathrm{~m}$. Thus, if pedestrian bridges are replaced by automobile bridges with only one unit-direction motion, sidewalk, and, preferably, a cycle path, the capacity of cars through the considered fragment of the Yauza will be comparable to the capacity of the Moscow Ring Road. If most of the gaps, of which there are several hundred in the city, along the lengthy obstacles of the city's road network in the form of rivers and highways, are stitched together by bridge buildings (BB), then the problem of traffic jams will be largely solved.

\section{RESULTS AND DISCUSSION}

Structures of the BB type, which combine transport (pedestrian and horse-drawn), residential, commercial, economic, and other functions of human activity, have been known since the European Middle Ages. The most famous multifunctional representative of this type of structure is the Ponte Vecchio bridge on the Arno River in Florence, built in 1345 by the architect Neri di Fioravanti (Figure 2). In addition to the transport function (horse-drawn carriages traveled along it), the bridge carried three-story houses with jewelry shops on the first floors, workshops on the second, and housing on the third floors. The bridge has been preserved physically and functionally to this day. The principle of constructive work of this structure: "The building puts the load on the bridge" is also used in modern architecture, for example, the project of the BB in Seoul (Figure 3). 


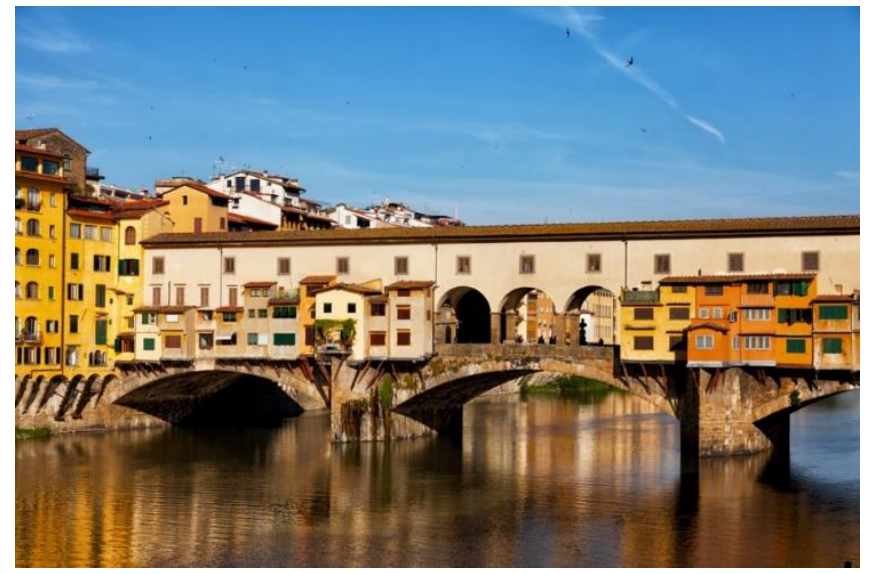

Figure 2. The Ponte Vecchio bridge in Florence. Architect Neri di Fioravanti

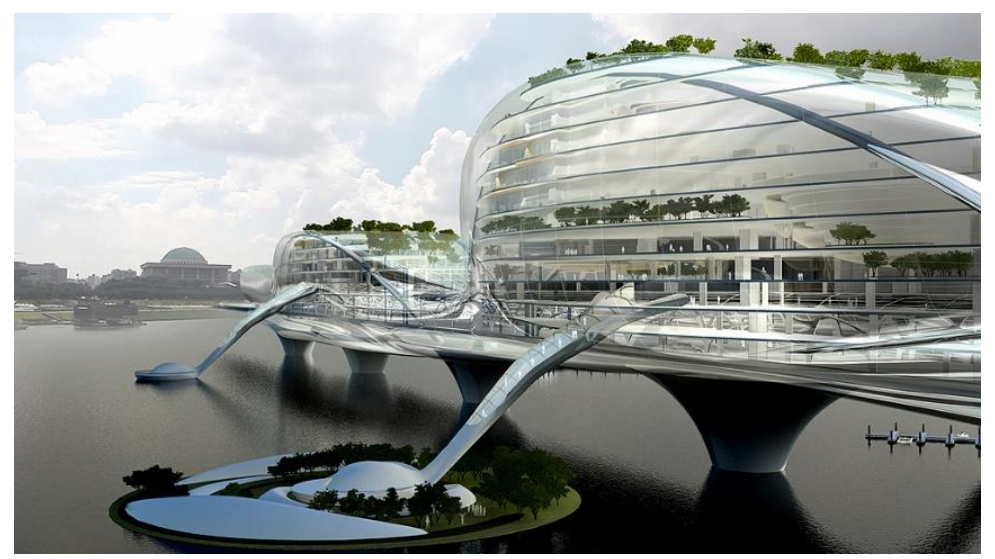

Figure 3. Visualization of the Paik Nam June Media Bridge project in Seoul

Today, a more advanced principle of BB operation - "structural shell" (Andrienko, 2020) is used. A vivid example of the application of this principle is the residential country house presented in Figures 4 and 5, the entire volume of which is included in the dimensions of the supporting bridge structure, which consists of two parallel trusses connected in the planes of the lower chords by beam and panel elements carrying the floor, and with the same beam and panel elements carrying a gable roof in planes of the upper chords. Panel and window elements, supported by truss elements, form the outer walls. All panel elements are equipped with thermal insulation layers that provide a comfortable indoor climate. Load-bearing trusses are placed outside the outer walls, presenting the clear structure of the house. In this building, following its purpose, a transport function is not provided, however, it clearly shows the combination of bearing and enclosing functions in its design. The principle demonstrated in this example allows saving a significant amount of materials for the construction of a house and carrying out its free planning. 


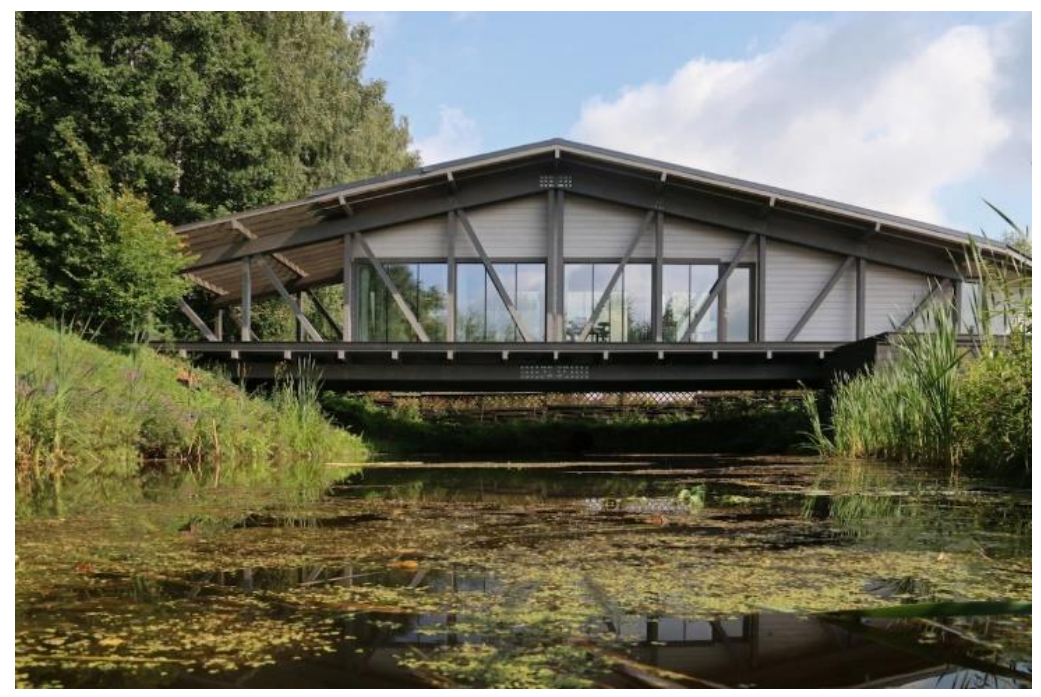

Figure 4. Residential BB in the Tula region. BIO-architects design office

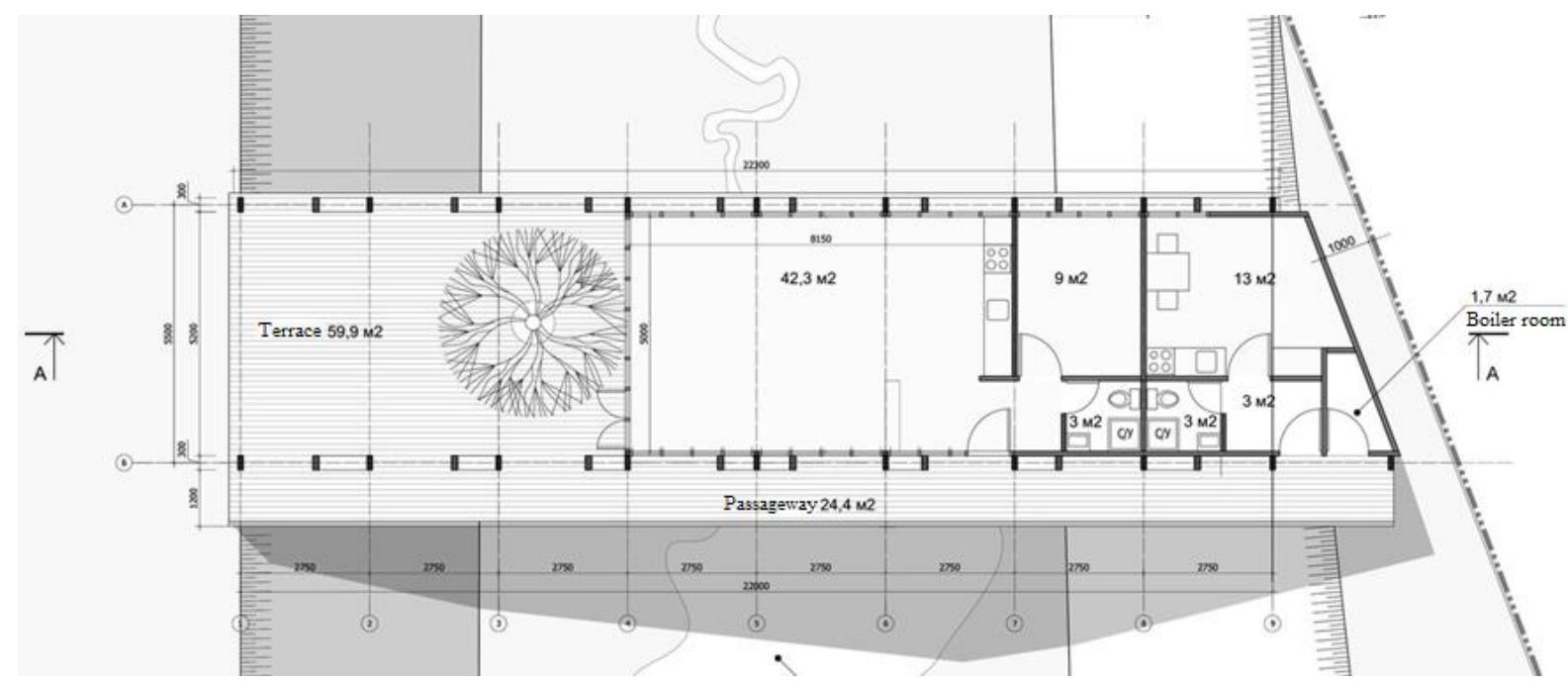

Figure 5. Plan of a residential BB in the Tula region. BIO-architects design office

At the Department of Architecture of the MSUCE, we used a new principle of BB erection, which is designated by the terms "self-supporting structure" and "structural shell", and the structures of BB (Zabalueva, Zakharov, Maslova, 2014) and load-bearing floor (Zabalueva, Zakharov, Ishkov, 2014) are patented on its basis. This principle allows significantly increasing the freedom of space-planning solutions, thereby increasing the versatility of buildings and reducing the cost of construction materials. Currently, the department conducts research and experimental design of buildings based on the principle of self-supporting structures and is developing various types of BBs suitable for various conditions of stitching the city's road network. In this development, it is necessary to achieve maximum unification of load-bearing structures of all types of $\mathrm{BB}$ and, first of all, intermediate floors, as the most massive elements.

The science and practice of erecting reinforced concrete and steel bridges of the beam type, as well as intermediate floors of buildings, have developed the most expedient in terms of strength and rigidity ratio between the building height and the span of building structures, like $1 / 20$. Thus, when the beam slab is 3 $\mathrm{m}$ long, its construction height is $0.15 \mathrm{~m}$; with a span of $4-6 \mathrm{~m}$, the building height is $0.2-0.3 \mathrm{~m}$ with a 
hollow or ribbed cross-section to save concrete. The construction height of these floors was from 5 to $10 \%$ of the floor height of $3 \mathrm{~m}$, respectively. A further increase in spans has led to the creation of steelreinforced concrete floor structures, which at a span of $20 \mathrm{~m}$ have a construction height of $1 \mathrm{~m}$, which is $30 \%$ of the height of the premise and leads to the need to increase the floor height to $4 \mathrm{~m}$. An increase in the construction height of the ceiling, forced by the requirements of strength and rigidity, leads to an undesirable increase in the heated volume of the building, reducing its efficiency. However, with rational design, a steel-reinforced concrete floor can provide significant advantages not only by increasing the freedom of planning a premise. In general, such a ceiling is a thin, $0.1 \mathrm{~m}$ thick, reinforced concrete slab with longitudinal and transverse ribs in the form of steel trusses, to which, if necessary, the ceiling is suspended. Thus, under the floors and above the ceilings of all floors, continuous cavities are formed in which all horizontal communication elements of the engineering and sanitary equipment of the building are freely placed. As a result, all premises are exempt from the need to place all these communications in them, which significantly compensates for the increase in the volume of the building due to the construction height of large-span ceilings. The positive effect of eliminating the entire volume of intermediate support structures should be added to this. As a result, the compactness of the building, with an increased construction height of steel-reinforced concrete floor structures, changes slightly.

At present, the dimensions of large-span steel-reinforced concrete structures of building floors and spans of small bridges have approached, which makes it possible to unify them for the construction of BB and, thereby, reduce the cost of their construction. Regardless of the building footprint and number of stories, BB made of these structures are usually called low-span or small (SBB) (Zabalueva, Fleishman, 2018). Examples of construction are the SBB project with a hotel in the floodplain of the Ramenka river by architect N. Vereshchagin (Figure 6) and the SBB project with the buildings of a residential building and hotel in the Yauza River floodplain by architect A.M. Andrienko (Figure 7) performed at the MSUCE (Andrienko, 2020).

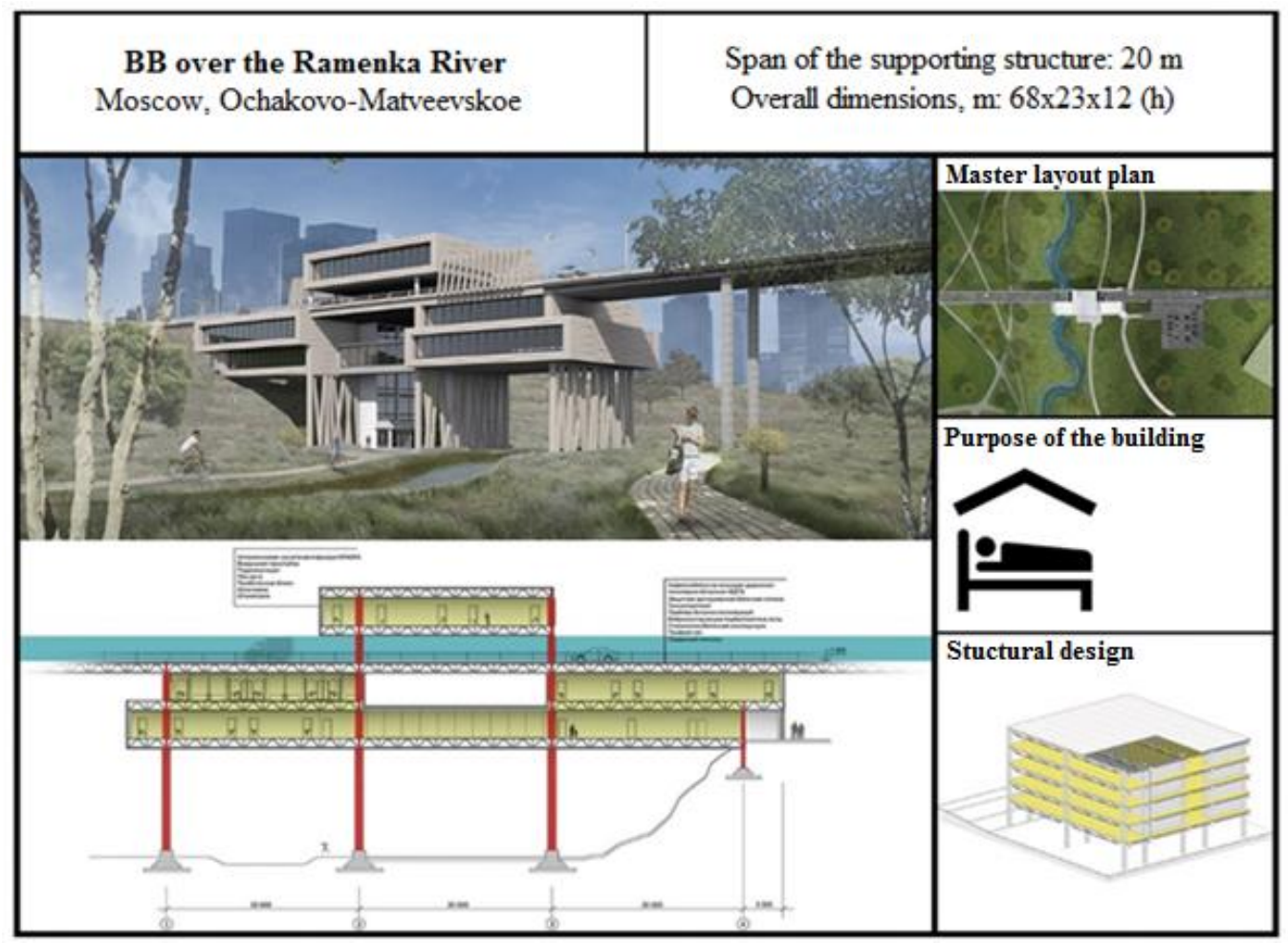

Figure 6. Project of a BB over the Ramenka River. Architect N. Vereshchagin 


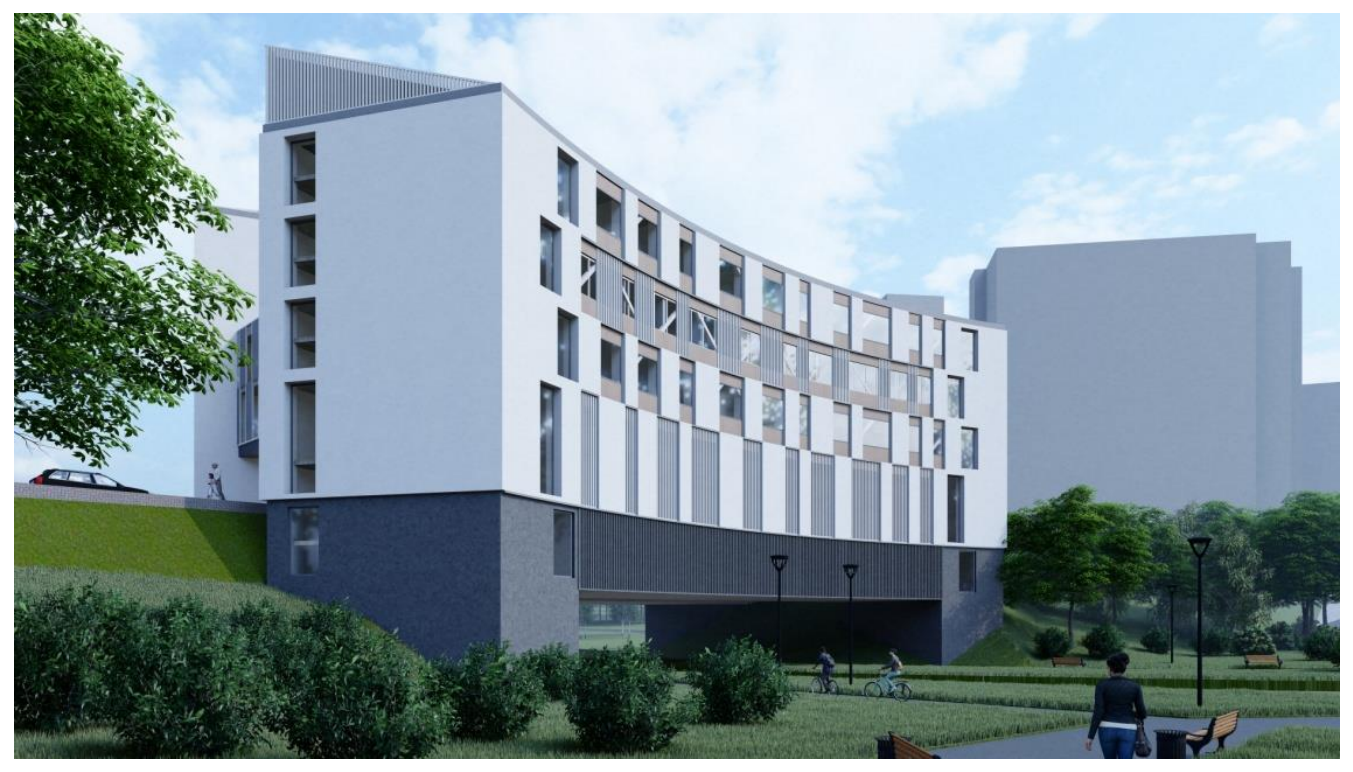

Figure 7. Model of a hotel and residential BB on the site of the Igarsky bridge in the Sviblovo district. Moscow. Architect A.M. Andrienko

The next step is in increasing the span of the "bearing floor" type of BB. It is a box-type structure, with a building height equal to the height of the floor. The shelves of the cross-section of the structure represent the bottom and top floors, the section walls represent the walls of the floor, tightly fastened to the floors. In the case under consideration, the steel-reinforced concrete floors presented above with a span of up to $20 \mathrm{~m}$ are advisable to be used as overlaps laid across the main span, and the structural basis of the walls can be the trusses of the main span of the BB, the construction height of which will consist of the height of the floor premise and two building heights of the floors. If the minimum height of the room is $3 \mathrm{~m}$, the minimum construction height of the $\mathrm{BB}$ of this type will be $5 \mathrm{~m}$, which can ensure its span of 30-50 m. Such a BB is usually called "medium" (MBB). An example of this type of construction is the BB shown in Figures 4 and 5 (Andrienko, 2020).

Finally, a large-span and multi-story BB (LBB), with a construction height of the bridge span equal to the full height of the building, is built according to the structural principle of the load-bearing floor of the $\mathrm{MBB}$, but has, if possible, a large number of floors, and spans up to $100 \mathrm{~m}$ or more. The economic efficiency of the construction cost of such an object can be estimated by the quantity and cost of structural materials per square $\mathrm{m}$ of the building's usable area. With an increase in the building height relative to the LBB span, the value of the given indicator decreases, increasing its economic efficiency. Thus, a ten-story LBB with a span of 100 , a height of 40 , and a width of $20 \mathrm{~m}$ (the ratio of the building height to the span is $1 / 2,5)$, as calculations show, has a value of the reduced indicator of consumption of construction materials close to that of a skyscraper with a height of 100 and 20x40 $\mathrm{m}$ in the plan (Andrienko, 2020). An example of an LBB with a span of $70 \mathrm{~m}$, with a residential function, being erected in the floodplain of the Ramenka River is a project carried out at the MSUCE by architect A. Dobromilskaya (Figure 8). 


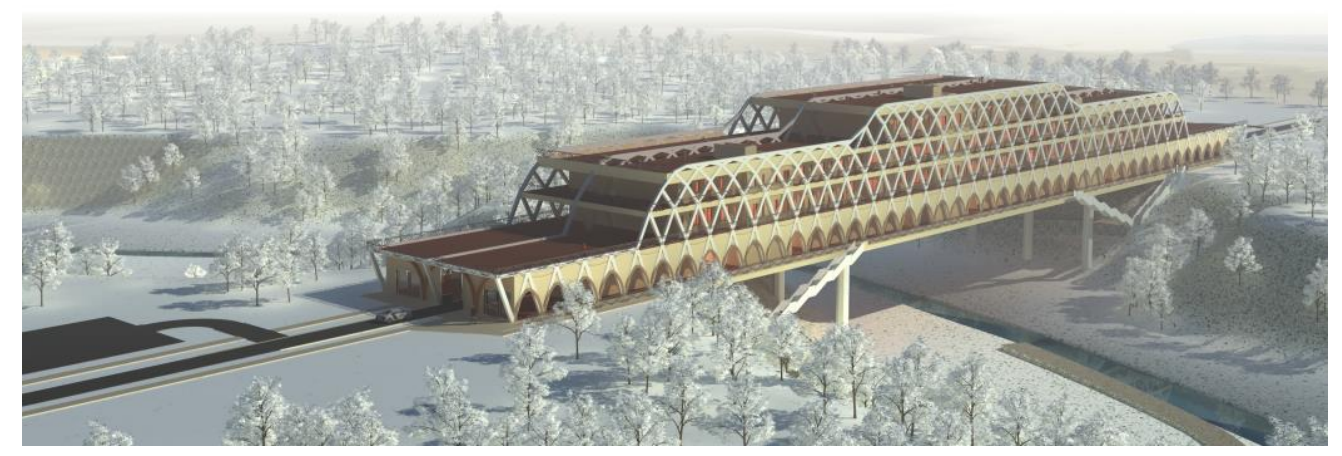

Figure 8 . BB across the floodplain of the Ramenka river with a gallery-type dwelling on the floors. Architect A. Dobromilskaya

The examples given in the article represent only a small part of the projects completed in the world and the actual construction of BB. The vast majority of projects do not provide for an automobile transport function (Razgulova, 2016; Pokka, 2014), and the transport passage has been replaced by a pedestrian zone for numerous tourists on the existing BB Ponte Vecchio. The passage of only passenger cars and vehicles equivalent to it is provided for in residential projects of BB developed at MSUCE, as well as in residential areas of the city. Also, the projects provide for the movement of cars only in a space completely isolated by enclosing structures from the rest of the building space, that is, in a kind of tunnels for safety reasons, protection from noise and gas pollution (Zabalueva, Fleishman, 2018).

\section{CONCLUSION}

1. A study of the city's road network showed its widespread tearing at local streets and significant - on district streets at their intersections with channels and floodplains of small rivers and railways.

2. The construction of city highways does not give the expected effect of reducing traffic congestion since cars rush to them from the adjacent broken local and district streets in an amount that exceeds the actual throughput of highways. At the same time, the adjacent streets are empty, their capacity is not being fully utilized.

3. To solve the problem of eliminating road congestion, it is necessary to "stitch" the road network by building bridges over long obstacles, in an amount exceeding the number of bridges existing in the city.

4. To raise funds for construction, it is necessary to erect BBsinstead of conventional bridges, in which, along with the carriageway, there will be premises (including predominantly rented) to carry out the functions necessary for the city. The set of functions and their scope should ensure a quick payback for the construction of the $\mathrm{BB}$ and further income acceptable to the investor.

5. At the MSUCE, scientific and design work is underway on the problem of creating BB for various purposes. A typological range of design and planning solutions is being developed to achieve the greatest social and economic efficiency as a result of the use of BB.

\section{REFERENCES}

Andrienko, A-M. (2020). Razrabotka printsipov arkhitekturnogo formirovaniya zdanii-mostov s gostinichnoi funktsiei dlya renovatsii territorii r. Yauza: dis... magistra arkhitektury [Development of principles for the architectural formation of bridge buildings with a hotel function for the renovation of the territory of the Yauza: Master of Architecture thesis]. Moscow: MSUCE. 
Kocheshkova, E.I. (2013). Arkhitekturno-planirovochnye resheniya nadzemnykh bolsheproletnykh zdanii: na primere goroda Moskvy: dis.... kand. arkhitektury [Architectural and planning solutions of overground large-span buildings: on the example of the city of Moscow: dissertation of the candidate of architect]. Moscow.

Pokka, E.V. (2014). Printsipy arkhitekturno-prostranstvennogo formirovaniya mnogofunktsionalnykh peshekhodnykh mostov: dissertatsiya ... kandidata arkhitektury [Principles of architectural and spatial formation of multifunctional pedestrian bridges: dissertation ... of a candidate of architecture]. Nizhny Novgorod.

Razgulova, A.M. (2016). Kontseptsiya sovmeshcheniya mosta i gorodskogo parka v kachestve gradoekologicheskoi svyazi na pogranichnykh sredovykh uchastkakh [The concept of combining the bridge and the city park as a city-ecological link in the border areas]. Architecture and Modern Information Technologies, 2(35), 11.

Zabalueva, T.R., Fleishman, S.L. (2018). Maloproletnye zdaniya-mosty s parkovochnoi funktsiei kak alternativa individualnym garazham [Small-span bridge buildings with parking function as an alternative to individual garages]. Moscow: LLC "Publishing house PGS".

Zabalueva, T.R., Zakharov, A.A., Ishkov, A.D. (2014). RF patent No. 2536594. Zdanie s bolsheproletnym pomeshcheniem [Building with a large premise].

Zabalueva, T.R., Zakharov, A.A., Maslova, T.A. (2014). Building-bridge. Patent of Russia No. 2513231.2014. Bul. No. 11.

Zabalueva, T.R., Zakharov, A.V., Kocheshkova, E.I. (2013). Zdaniya-mosty - reshenie problemy avtomobilnykh probok v krupneishikh gorodakh [Bridge buildings - solving the problem of traffic jams in the metropolises]. Promyshlennoe i grazhdanskoe stroitelstvo [Industrial and civil construction], 9, 32-35. 